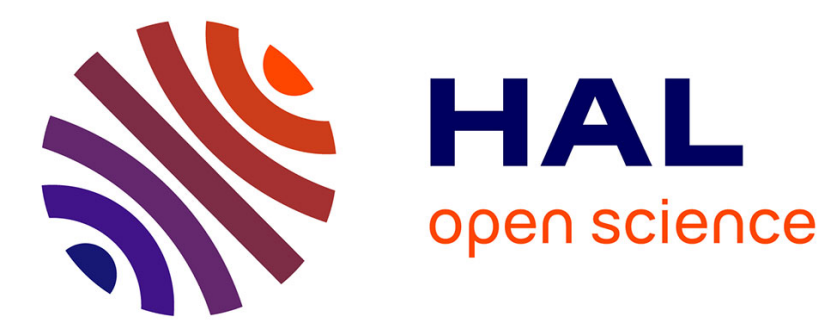

\title{
Transrectal endoscopic treatment of gallstone ileus
}

S. Lafitte, R. Hanafi, F. Browet

\section{To cite this version:}

S. Lafitte, R. Hanafi, F. Browet. Transrectal endoscopic treatment of gallstone ileus. Journal of Visceral Surgery, 2019, 156, pp.269 - 270. 10.1016/j.jviscsurg.2018.10.002 . hal-03486471

\section{HAL Id: hal-03486471 https://hal.science/hal-03486471}

Submitted on 20 Dec 2021

HAL is a multi-disciplinary open access archive for the deposit and dissemination of scientific research documents, whether they are published or not. The documents may come from teaching and research institutions in France or abroad, or from public or private research centers.
L'archive ouverte pluridisciplinaire HAL, est destinée au dépôt et à la diffusion de documents scientifiques de niveau recherche, publiés ou non, émanant des établissements d'enseignement et de recherche français ou étrangers, des laboratoires publics ou privés.

\section{다)(1) $\$$}

Distributed under a Creative Commons Attribution - NonCommercial| 4.0 International 
Version of Record: https://www.sciencedirect.com/science/article/pii/S1878788618301474 Manuscript_ef13d3dbd08b0d779ce41c31ce05eedf

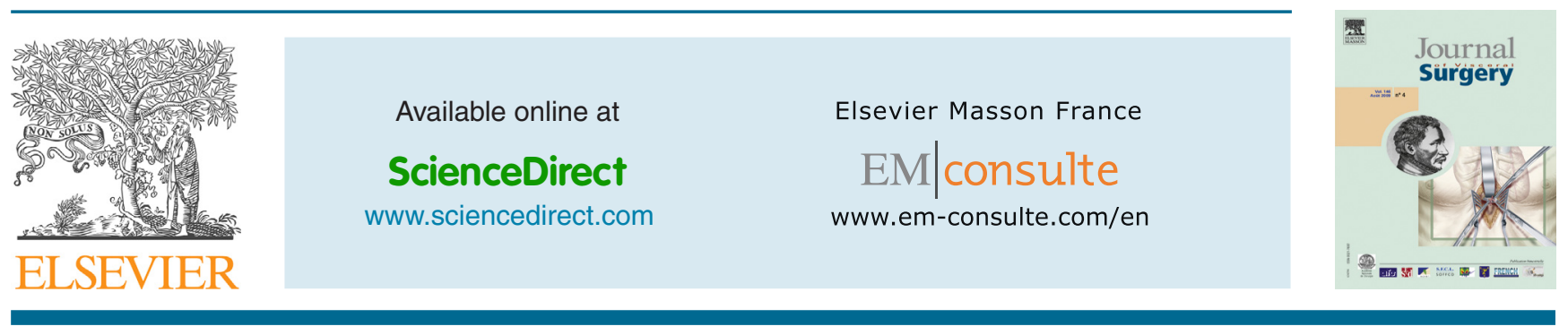

\title{
SURGICAL IMAGES
}

\section{Transrectal endoscopic treatment of gallstone ileus}

\section{S. Lafitte ${ }^{a}$, R. Hanafi ${ }^{b}, F$. Browet ${ }^{a, c, d, *}$}

a Service de chirurgie viscérale et digestive, centre hospitalier de Beauvais, 40, avenue Léon-Blum, 60000 Beauvais, France

b Service de radiologie, centre hospitalier de Beauvais, 40, avenue Léon-Blum, 60000 Beauvais, France

' Unité de recherche clinique, centre hospitalier de Beauvais, 40, avenue Léon-Blum, 60000 Beauvais, France

dUnité de recherche «soins des patients chirurgicaux complexes", université de Picardie Jules-Vernes, boulevard de Chateaudain, 80000 Amiens, France

Available online 18 January 201

\begin{abstract}
A 71-year-old woman sought emergency care for diffuse abdominal pain. The clinical presentation was intestinal obstruction in the last 24 hours with no sign of complication. There was no hernia and the digital rectal examination was normal. One month earlier, the patient had experienced an episode of acute cholecystitis with sonographic evidence of biliary cholelithiasis. Cholecystectomy was scheduled six weeks later. During the four weeks since the acute episode, the patient had lost weight $(15 \mathrm{~kg})$ and experienced alternating diarrhea and transient constipation. Blood tests revealed no sign of inflammation and liver tests were normal. Computed tomography of the abdomen and pelvis demonstrated colonic distension reaching the rectosigmoid junction and a change in caliber in contact with a rosette image with peripheral calcification (Figs. 1 and 2). We retained the diagnosis of gallstone ileus related to a cholecysto-colonic fistula. Transrectal endoscopic treatment was feasible: the gallstone was mobilized and successfully extracted per rectally. Lithotrity was not necessary (Figs. 3 and 4). The postoperative follow-up revealed that the cholecysto-colonic fistula was a benign complication of xantho-granulomatous cholecystitis.
\end{abstract}

\footnotetext{
* Corresponding author at: Secrétariat chirurgie viscérale et digestive, avenue Léon-Blum, 60021 Beauvais cedex, France.
} E-mail address: f.browet@ch-beauvais.fr (F. Browet).

https: //doi.org/10.1016/j.jviscsurg.2018.10.002

1878-7886/@ 2018 Elsevier Masson SAS. All rights reserved. 


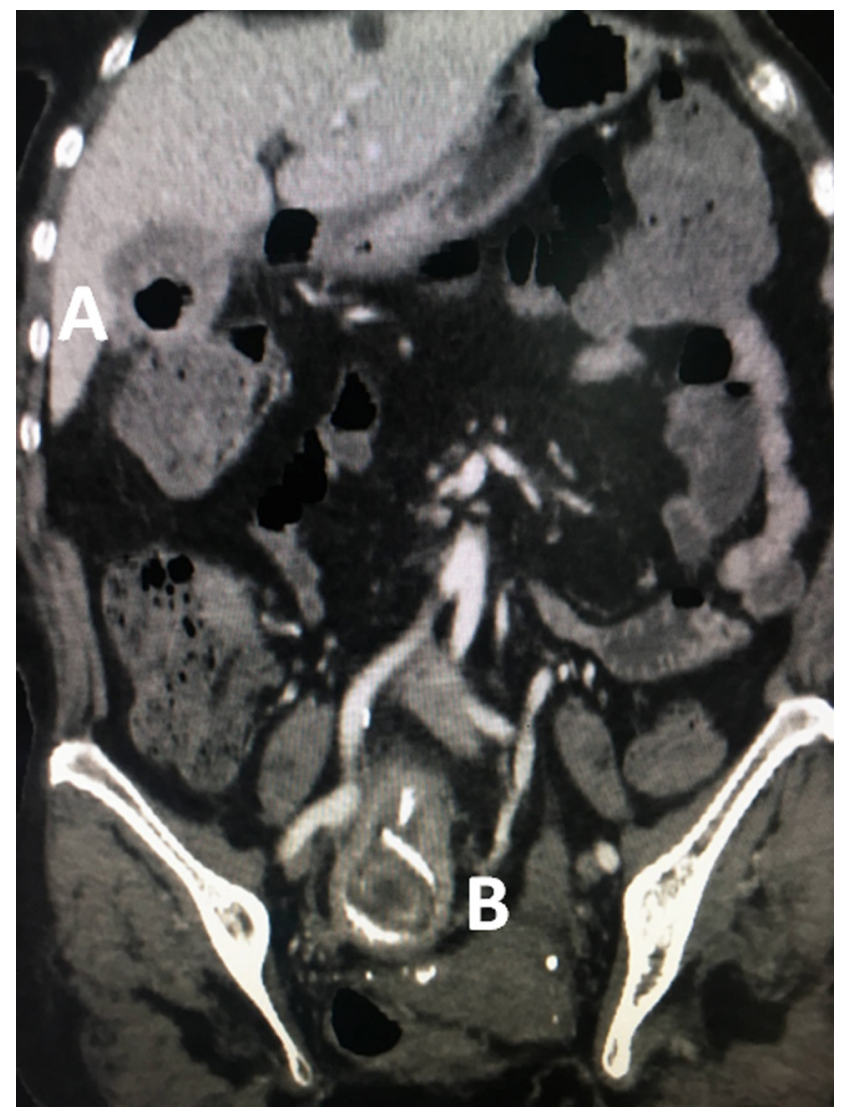

Figure 1. Computed tomography of the abdomen and pelvis with contract injection (portal time). Frontal slice through (A) the cholecysto-colonic fistula; and (B) the intra-sigmoidal stone.

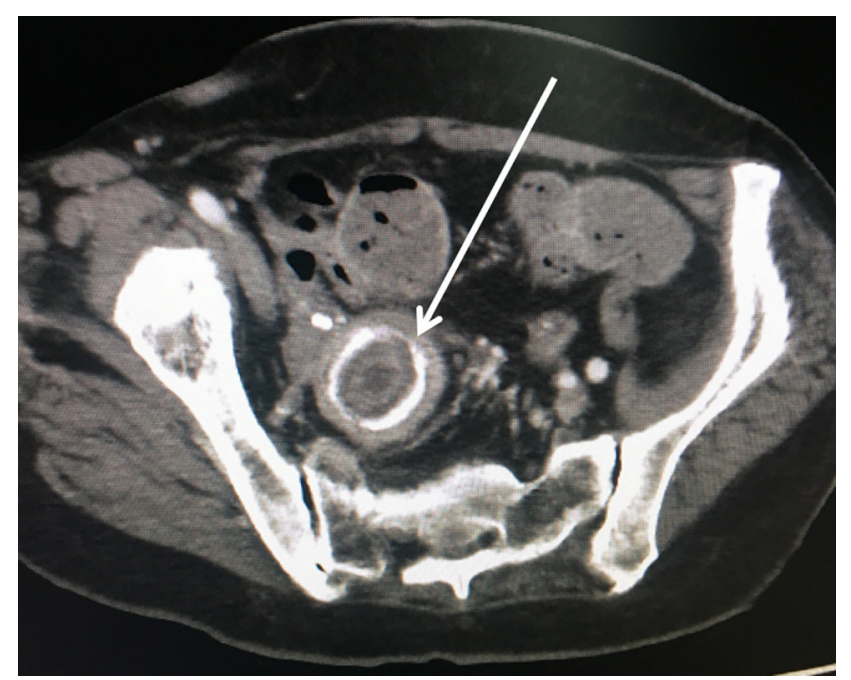

Figure 2. Computed tomography of the abdomen and pelvis with contrast injection (portal time). Transverse slice through a round rosette image with peripheral calcification suggestive of an intracolonic gallstone in the rectosigmoid junction.

Gallstone ileus is rare (1\% of digestive obstructions) [1] and even more so when caused by an intra-colonic stone (4\% of gallstone ileus cases). This clinical situation is observed predominantly in women aged 60 years or over [2]. The case we describe illustrates the usefulness of computed tomography to precisely identify the cause of the obstruction. Open surgical extraction is the gold standard for gallstone ileus in order to remove the obstacle and search for other stones,

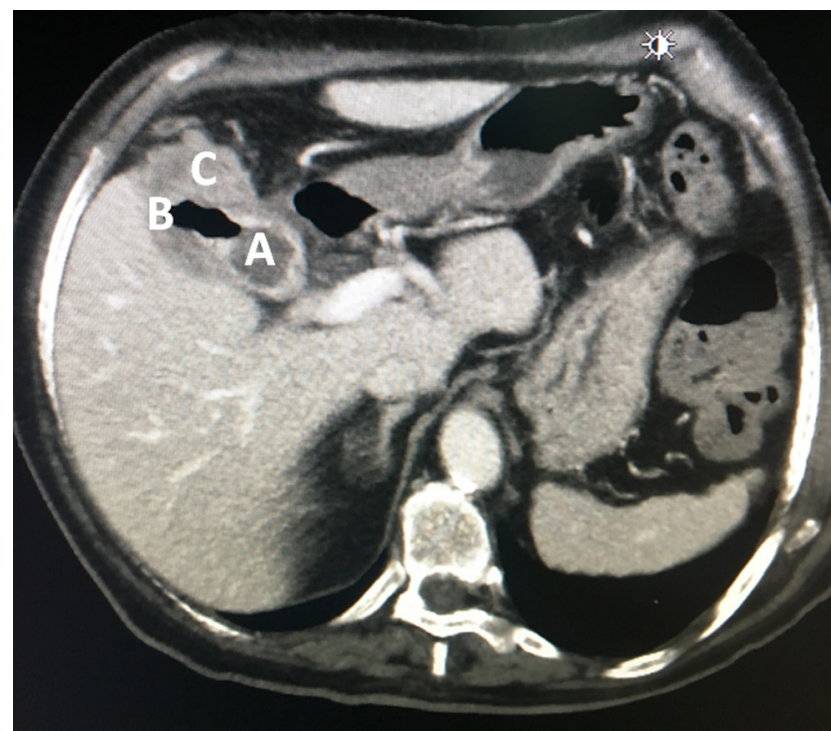

Figure 3. Computed tomography of the abdomen and pelvis with contrast injection (portal time). This transverse slice shows (A) the gallbladder (thick walls, air); (B) the cholecysto-colonic fistula; (C) and the inflammatory right transverse colon in contact with the fistula.

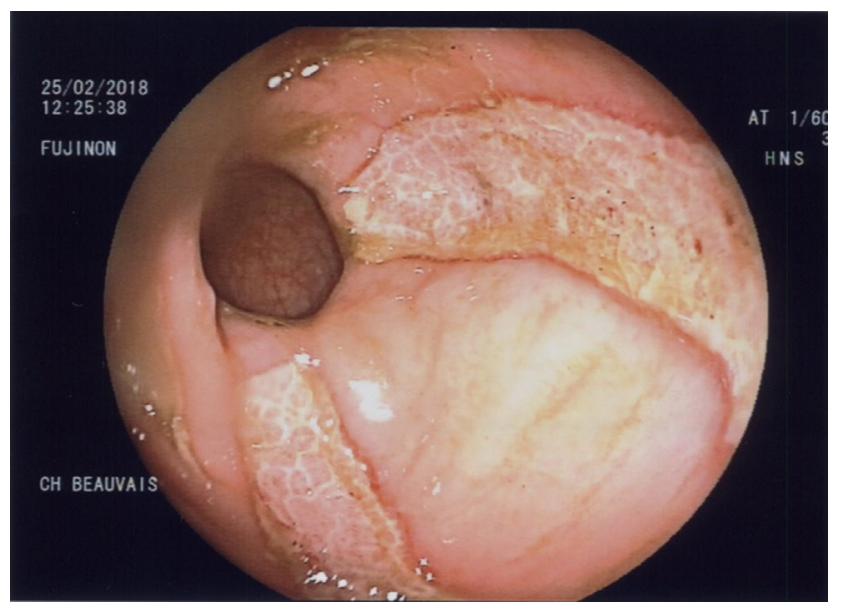

Figure 4. Transrectal endoscopy image showing the erosion of the rectosigmoid mucosa caused by the gallstone.

in addition to treating the cholecysto-colonic fistula as proposed by some authors. The gallstone is generally embedded in the ilium, prohibiting an endoscopic approach. Nevertheless, in our case transrectal endoscopy was possible and successful, a rare example of less invasive treatment for fragile elderly patients.

\section{Disclosure of interest}

The authors declare that they have no competing interest.

\section{References}

[1] Clavien PA, Richon J, Burgan S, et al. Gallstone ileus. Br J Surg 1990;77:737-42.

[2] Reisner RM, Cohen JR. Gallstone ileus: a review of 1001 reportedcases. Am Surg 1994;60:441-6. 